\title{
Pollen morphology of Brazilian species of Verbesina L. (Heliantheae - Asteraceae) $)^{1}$
}

\section{Giselle Lopes Moreira ${ }^{2 *}$ (D), Taciana Barbosa Cavalcanti ${ }^{3}$ (D), Cláudia Barbieri Ferreira Mendonça ${ }^{4}$ (D) and Vânia Gonçalves-Esteves ${ }^{4}$ (1)}

Received: November 10, 2018

Accepted: December 18, 2018

\begin{abstract}
There are nine species of the plant genus Verbesina in Brazil, which are distributed in the Northeast, Center-West, Southeast and South regions of the country. The objective of the present study was to describe the pollinic morphology of eight of these species to better characterize them and evaluate potential species-level taxonomic characters. Acetolysed pollen material was measured within seven days under light microscopy, while non-acetolyzsed pollen grains were used for scanning electronic microscopy. The pollen grains were found to be oblate-spheroidal, mediumsized, isopolar, monads that are 3-colporate with a subtriangular amb, a small polar area, a long colpus, a lalongate endoaperture, a caveate exine and an echinate sexine. Although the shape of the pollen grains of these Brazilian species of Verbesina is homogeneous, some attributes were observed to be useful for characterizing the species, such as exine thickness, distance between spines and side of the apocolpus.
\end{abstract}

Keywords: Brazil, Compositae, Heliantheae, morphology, pollen, Verbesina

\section{Introduction}

The family Asteraceae, order Asterales (APG IV 2016) has a holistic distribution but is common in the dry and open tropical montane climate zone (Anderberg et al. 2007). The family includes 13 subfamilies, 44 tribes, about 1,700 genera and proximately 27,000 species, and represents about $10 \%$ of all Angiosperms (Funk et al. 2009; Panero et al. 2014; Panero \& Crozier 2016). There are about 2,097 species of Asteraceae grouped among 289 genera in Brazil (Flora do Brasil 2020).

The genera Verbesina belongs to the tribe Heliantheae (subtribe Verbesininae) and possesses around 300 species distributed throughout the Americas, with the most occurring in Mexico and the Andes (Panero 2007). Nine species have been recorded in Brazil, which are distributed in the Northeast, Southeast, Center-West and South regions of the country, especially in forest environments.

Pollen morphology has contributed to characterizing and differentiating taxa of Asteraceae at the subfamily, tribe and subtribe levels (Skvarla \& Turner 1966; Bolick 1991; Cancelli et al. 2007; Coutinho \& Dinis 2007; Wortley et al. 2007; Stanski et al. 2016; among others), however, few studies have focused on pollen morphology for distinguishing species of Asteraceae because pollen grains have been found to be morphologically homogeneous within the same genus (Gonçalves 1976). Nonetheless, pollen morphology has been used to distinguish species of some genera of the tribe Heliantheae, such as Ambrosia, Clibadium, Eclipta, Parthenium, Viguiera, Xanthium and Wedelia (GonçalvesEsteves \& Esteves 1986; 1989a; b).

1 Part of the doctoral thesis of the first author.

2 Universidade de Brasília, 70910-900, Brasília, DF, Brazil

3 Embrapa Recursos Genéticos e Biotecnologia, 70770-917, Brasília, DF, Brazil

4 Museu Nacional, Universidade Federal do Rio de Janeiro, 20940-040, Rio de Janeiro, RJ, Brazil

* Corresponding author: giselle.bio25@gmail.com 
Most studies involving pollen morphology of Verbesina have been descriptive, such as Gonçalves (1976), who analyzed 17 species, including three Brazilian species (Verbesina diversifolia $[=V$. macrophylla], V. glabrata and $V$. sordescens); Roubik \& Moreno (1991) who studied V.gigantea of Panama; Sanchez \& Lupo (2009) who investigated V. lilloi from Argentina; and Jesus \& Lima (2013) who reported on V. macrophylla from Bahia, Brazil. Other references to Verbesina are pollen catalogs such as Cancelli et al. (2010) for Rio Grande do Sul, Brazil, with V. glabrata and V. sordescens; and Radaeski et al. (2014; 2016) with V. sordescens.

Some studies that have addressed the pollen morphology of Verbesina have indicated the existence of characters with potential use for characterizing and differentiating species of the genus. Harker \& Jiménez-Reyes (2002) found that some pollen grain characters, such as shape, size, number of spicules, transverse size colpus and polar area index, were useful for separating Verbesina barrancae and V. crocata, two morphologically close Mexican species.

The objective of the present study was to describe the pollen morphology of eight Brazilian species of Verbesina to better characterize the species of the genus and to evaluate potential species-level taxonomic characters.

\section{Materials and methods}

Pollen material was obtained from floral buds of specimens of eight species of Verbesina (V. baccharifolia Mattf., V. bipinnatifida Baker, V. floribunda Gardner, V. glabrata Hook. \& Arn., V. luetzelburgii Mattf., V. macrophylla (Cass.) S.F. Blake, V. nicotianifolia Baker, $V$. sordescens DC.) deposited in the following herbaria: BHCB, CEN, HUCS, HUEFS, MBML, RB, UB (Thiers 2017) (Tab. 1).

Pollen material was prepared for light microscopy using acetolysis following the method of Erdtman (1952), with the modifications proposed by Melhem et al. (2003). Acetolysed pollen grains were measured within seven days of their preparation, in accordance with Salgado-Labouriau (1973). Twenty-five measurements of polar diameter (PD) and equatorial diameter (ED) in equatorial view, and 10 measurements of the equatorial diameter in polar view (EDPV) and apocolpium side (AS), were made on standard material distributed among at least three slides. For other dimensions, such as those of apertures, exine layers and diameters of comparison material, 10 pollen grains were measured on at least in three slides and the arithmetic mean calculated. Description of polar area and aperture size followed the classification established by Faegri \& Iversen (1966) for the polar area index. Pollen grain size classes follow Erdtman (1952).

Permanent slides of pollen material generated for this study are deposited in the Laboratory of Palynology of the National Museum of the Federal University of Rio de Janeiro.
For scanning electron photomicrography, two to three anthers were removed from flowers or flower buds extracted from herbarium specimens. The anthers were macerated using properly flamed forceps and stylus to release nonacetolysed pollen grains over a metallic stub previously covered with double-sided carbon tape. The material was spatter-coated with gold for approximately three minutes and then analyzed and photomicrographed using a JSM5310 scanning electron microscope at the Optical and Scanning Microscopy Laboratory, Federal University of Rio de Janeiro.

To assess whether pollen characteristics discriminated the studied species of Verbesina, a principal component analysis (PCA) was performed using eleven metric variables. The results were biplotted on a graph with axes 1 and 2 of the PCA.

\section{Results}

The pollen grains of the studied species of Verbesina were found medium-sized $(25-50 \mu \mathrm{m})$ oblate-spheroidal, isopolar, monads with a subtriangular amb, (PD/ED 0.95-0.99) (Tab. 2).

The confidence interval $95 \%$ for polar diameter (PD) in equatorial view ranged 25.3-42.3 $\mu \mathrm{m}$, with the lowest values being for Verbesina macrophylla $(25.3-26.3 \mu \mathrm{m})$ and the greatest for V. baccharifolia (39.5-42.3 $\mu \mathrm{m})$ (Tab. 2).

All species had a low polar area index $(0.35-0.48 \mu \mathrm{m})$ (Tab. 2), were 3-colporate, and had: long colpus (9.3-14.5 x 2.9-5.0 $\mu \mathrm{m})$, acute apices, lalongate endoaperture (2.2-4.6x 8.8-14.2 $\mu \mathrm{m})$ with constriction, caveate exine (2.2-3.4 $\mu \mathrm{m})$ echinate sexine, spines $(4.0-5.9 \times 3.0-4.1 \mu \mathrm{m})$ with perforations at the base, and distance between spines of 6.1-8.6 $\mu \mathrm{m}$. The colpus with medium constrictions is more perceptible in $V$. floribunda. The longest colpus was found in Verbesina luetzelburgii $(14.5 \mu \mathrm{m})$ and the shortest in $V$. nicotianifolia $(9.3 \mu \mathrm{m})$; V. luetzelburgii $(4.6 \mu \mathrm{m})$ had the longest endoaperture while $V$. bipinnatifida $(2.2 \mu \mathrm{m})$ had the shortest; and $V$. floribunda $(14.2 \mu \mathrm{m})$ had the largest endoaperture while V. bipinnatifida and V.macrophylla $(8.8 \mu \mathrm{m})$ had the smallest (Tab. 3).

In all species the exine was found to be caveate and echinate (Figs. 1, 2). The sexine and nexine were almost always of the same thickness, but when they did differ the sexine was thicker than the nexine. Mean width exine ranged 2.2-3.4 $\mu \mathrm{m}$ (Tab. 3). The sexine and nexine are very close to the cavea, making it difficult to see.

Four to six pairs of spines were observed around the aperture in equatorial view (Figs. 1D, H, L, P, 2D, H, L, P), which were longer than wide and with perforations at the base. The shortest spines were found in Verbesina macrophylla $(4.0 \mu \mathrm{m})$ while the longest were for V. baccharifolia $(5.9 \mu \mathrm{m})$. The distance between spines varied (6.1-8.6 $\mu \mathrm{m})$, with it being the greatest in $V$. floribunda $(8.6 \mu \mathrm{m})$ and least in $V$. sordescens $(6.1 \mu \mathrm{m})$ (Tab. 3$)$. 
Table 1. Species used in the morphological analysis of pollen grains in Verbesina L. (Asteraceae-Heliantheae).

\begin{tabular}{|c|c|c|}
\hline Species & Voucher & Herbarium \\
\hline Verbesina baccharifolia Mattf. & Ganev 363, Ganev 1824, Ganev 1928 & HUEFS, HUEFS, HUEFS \\
\hline Verbesina bipinnatifida Baker & Moreira et al. 116, Vervloet \& Bausen 164, Lombardi \& Salino 1671 & CEN, MBML, BHCB \\
\hline Verbesina floribunda Gardner & Moreira et al. 102, Moreira et al. 101, Forzza et al. 3066 & CEN, CEN, RB \\
\hline Verbesina glabrata Hook. \& Arn. & Moreira et al. 115, Fontana \& Toniato 619, Moreira et al. 103 & CEN, BML, CEN \\
\hline Verbesina luetzelburgii Mattf. & Moreira et al. 117, Moreira et al. 118, Moreira et al. 119 & CEN, CEN, CEN \\
\hline Verbesina nicotianifolia Baker & Proença 865 & UB \\
\hline Verbesina macrophylla (Cass.) S.F. Blake & Moreira et al. 112, Moreira et al. 110, Moreira et al. 111 & CEN, CEN, CEN \\
\hline Verbesina sordescens DC. & Wasum s.n., Wasum 3706, Scur 1136 & HUCS 12414, HUCS, HUCS \\
\hline
\end{tabular}

Table 2. Measurements of pollen grains in Brazilian Verbesina L. (Heliantheae-Asteraceae) species in equatorial view: ( $\mathrm{n}=25)$ and polar view: $(\mathrm{n}=10)$; PAI = polar area index.

\begin{tabular}{|c|c|c|c|c|c|c|}
\hline \multirow{2}{*}{ Species } & \multicolumn{3}{|c|}{ Equatorial View } & \multicolumn{3}{c|}{ Polar View } \\
\cline { 2 - 7 } & Polar diameter $(\mu \mathrm{m})$ & Equatorial diameter $(\mu \mathrm{m})$ & PD/ED & Equatorial Diameter $(\mu \mathrm{m})$ & Apocolpous Side $(\mu \mathrm{m})$ & PAI \\
\hline V. baccharifolia Mattf. & $35.0(40.9) 50.0$ & $37.5(41.9) 50.0$ & 0.98 & $37.5(41.5) 45.0$ & $15.0(17.8) 22.5$ & 0.43 \\
\hline V. bipinnatifida Baker & $27.5(31.0) 40.0$ & $27.5(31.9) 40.0$ & 0.97 & $25.0(31.2) 35.0$ & $10.0(13.5) 15.0$ & 0.43 \\
\hline V. floribunda Gardner & $30.0(34.2) 45.0$ & $30.0(35.6) 42.5$ & 0.96 & $32.5(36.0) 40.0$ & $10.0(12.5) 15.0$ & 0.35 \\
\hline V. glabrata Hook. \& Arn. & $30.0(33.3) 37.5$ & $32.5(34.2) 37.5$ & 0.97 & $30.0(32.7) 35.0$ & $12.5(14.7) 15.0$ & 0.45 \\
\hline V. luetzelburgii Mattf. & $32.5(37.0) 40.0$ & $35.0(37.3) 40.0$ & 0.99 & $37.5(39.2) 42.5$ & $15.0(16.7) 17.5$ & 0.43 \\
\hline V. macrophylla (Cass.) S.F. Blake & $25.0(25.8) 27.5$ & $25.0(27.2) 30.0$ & 0.95 & $25.0(26.7) 27.5$ & $10.0(12.7) 15.0$ & 0.48 \\
\hline V. nicotianifolia Baker & $27.5(30.9) 35.0$ & $27.5(31.4) 37.5$ & 0.98 & $30.0(32.7) 35.0$ & $12.5(14.2) 15.0$ & 0.43 \\
\hline V. sordescens DC. & $30.0(33.1) 37.5$ & $32.5(34.8) 37.5$ & 0.95 & $32.5(35.0) 37.5$ & $15.0(16.2) 17.5$ & 0.46 \\
\hline
\end{tabular}

Table 3. Measurements of the aperture and layers of exine pollen grains in Brazilian Verbesina L. species (Heliantheae-Asteraceae); $\mathrm{n}=10$; DBS = distance between spines; ${ }^{*}$ measured without the spines.

\begin{tabular}{|c|c|c|c|c|c|c|c|c|c|c|}
\hline \multirow{2}{*}{ Specie } & \multicolumn{2}{|c|}{ Colpus } & \multicolumn{2}{|c|}{ Endoaperture } & \multicolumn{3}{|c|}{ Exine layers* } & \multicolumn{3}{|c|}{ Spine } \\
\hline & length $(\mu \mathrm{m})$ & width $(\mu \mathrm{m})$ & length $(\mathrm{mm})$ & width $(\mu \mathrm{m})$ & exine & sexine & nexine & length $(\mu \mathrm{m})$ & width $(\mu \mathrm{m})$ & DBS \\
\hline V. baccharifolia Mattf. & 14.4 & 5.0 & 4.4 & 12.6 & 3.3 & 1.7 & 1.6 & 5.9 & 4.1 & 7.9 \\
\hline V. bipinnatifida Baker & 11.5 & 3.2 & 2.2 & 8.8 & 3.4 & 1.7 & 1.7 & 4.5 & 3.5 & 7.0 \\
\hline V. floribunda Gardner & 10.6 & 2.9 & 4.3 & 14.2 & 3.4 & 1.9 & 1.5 & 5.3 & 3.3 & 8.6 \\
\hline V. glabrata Hook. \& Arn. & 14.1 & 4.5 & 4.2 & 12.3 & 2.8 & 1.4 & 1.4 & 5.0 & 3.1 & 7.5 \\
\hline V. luetzelburgii Mattf. & 14.5 & 4.6 & 4.6 & 12.7 & 3.3 & 1.7 & 1.6 & 5.8 & 3.7 & 6.9 \\
\hline V. macrophylla (Cass.) S.F. Blake & 9.7 & 3.3 & 3.7 & 8.8 & 2.6 & 1.6 & 1.0 & 4.0 & 3.0 & 6.7 \\
\hline V. nicotianifolia Baker & 9.3 & 3.9 & 3.0 & 9.5 & 2.2 & 1.2 & 1.0 & 4.8 & 3.0 & 6.5 \\
\hline V. sordescens DC. & 10.4 & 4.9 & 3.9 & 10.4 & 2.9 & 1.9 & 1.0 & 5.2 & 3.4 & 6.1 \\
\hline
\end{tabular}

Verbesina glabrata was the only species to exhibit variation in pollen grain shape, ranging from oblatespheroidal to prolate-spheroidal (Tabs. 2, 4). The mean $\mathrm{PD}$ and ED of the comparison material of $V$. macrophylla were $31.9 \mu \mathrm{m}$ and $32.6 \mu \mathrm{m}$, respectively, which differed from that of the standard material $(25.8 \mu \mathrm{m}$ and 27.2 $\mu \mathrm{m}$, respectively), however, pollen grain shape did not differ. The comparison material for the other species had means that fell within the range found for the standard material.

\section{Principal component analysis (PCA)}

The first two axes of the PCA explained $83.6 \%$ of the variability of the analyzed data. The first axes explained $64.8 \%$ of the data, with Verbesina bipinnatifida, V. macrophylla and $V$. nicotianifolia having, in general, the lowest values for $\mathrm{PD}, \mathrm{ED}, \mathrm{EDPV}$, colpus length, endoaperture length and spine length, while Verbesina baccharifolia and V. luetzelburgii had
Table 4. Measurements of pollen grains of comparison materials in Brazilian Verbesina L. (Heliantheae - Asteraceae) species in equatorial view: $\mathrm{n}=10 ; \overline{\mathrm{X}}=$ arithmetic mean.

\begin{tabular}{|c|c|c|c|}
\hline \multirow{2}{*}{ Species } & $\begin{array}{c}\text { Polar diameter } \\
\text { (PD) }\end{array}$ & $\begin{array}{c}\text { Equatorial diameter } \\
\text { (ED) }\end{array}$ & PD/ED \\
\cline { 2 - 3 } & $\overline{\mathbf{X}}$ & $\overline{\mathbf{X}}$ & \\
\hline V. baccharifolia Mattf. & 38.0 & 39.5 & 0.96 \\
\hline V. bipinnatifida Baker & 37.5 & 38.3 & 0.98 \\
\hline V. floribunda Gardner & 30.3 & 30.5 & 0.99 \\
\hline V. glabrata Hook. \& Arn. & 30.5 & 31.5 & 0.97 \\
\hline V. luetzelburgii Mattf. & 32.0 & 33.2 & 0.96 \\
\hline V. macrophylla (Cass.) S.F. & 34.2 & 35.2 & 0.97 \\
\hline Blake & 35.0 & 36.5 & 0.96 \\
\hline V. sordescens DC. & 36.7 & 37.7 & 1.02 \\
\hline & 31.5 & 38.5 & 0.95 \\
\hline
\end{tabular}


the highest values for these attributes. These attributes were closely correlated, as shown in Figure 3.

The second axis explained $18.8 \%$ of the data, with Verbesina floribunda having the highest values for distance between spines (DBS), exine thickness and endoaperture width, and the lowest values for the apocolpus side (AS) index and colpus width.

\section{Discussion}

Pollen grains of Verbesina can be classified as the "Aspilia" type described by Salgado-Labouriau (1973), because they are medium to large in size, 3-colporate, and lalongate, with an endoaperture with a medium constriction, an echinate exine and conical spines with perforations at the base.

Previous studies of Verbesina have shown that pollen grain shape can vary from suboblate to prolate-spheroidal (PD / ED 0.75-1.14), with oblate-spheroidal to prolatespheroidal being most common, as was reported by Gonçalves (1976) who analyzed 17 species of Verbesina, including three Brazilian species (V. diversifolia DC = $V$. macrophylla, V. glabrata and V. sordescens). These differences in pollen grain shape (Gonçalves 1976; Jesus \& Lima 2013; Radaeski et al. 2016) (Tab. 5) are
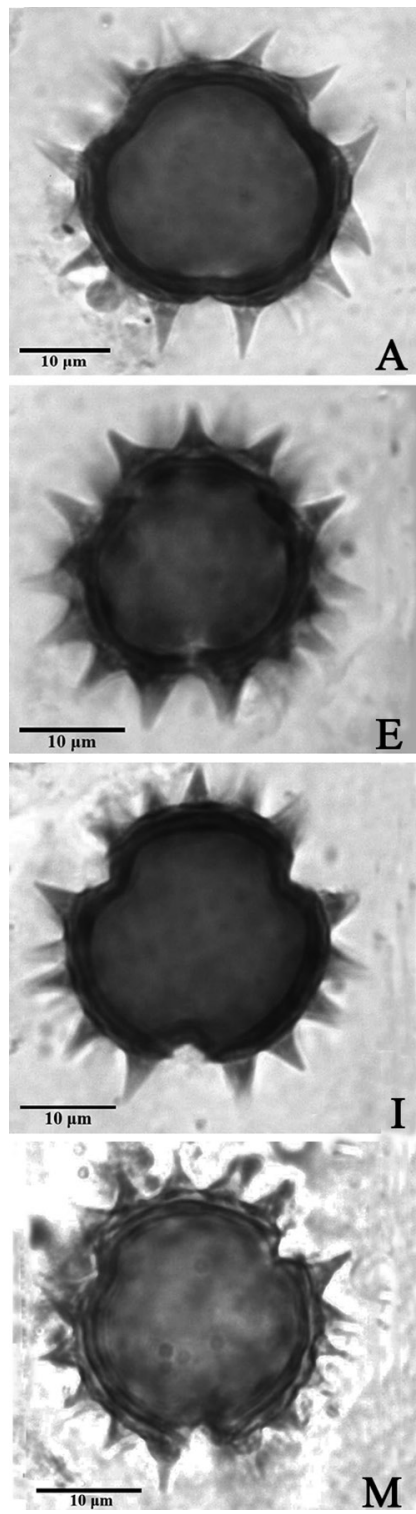
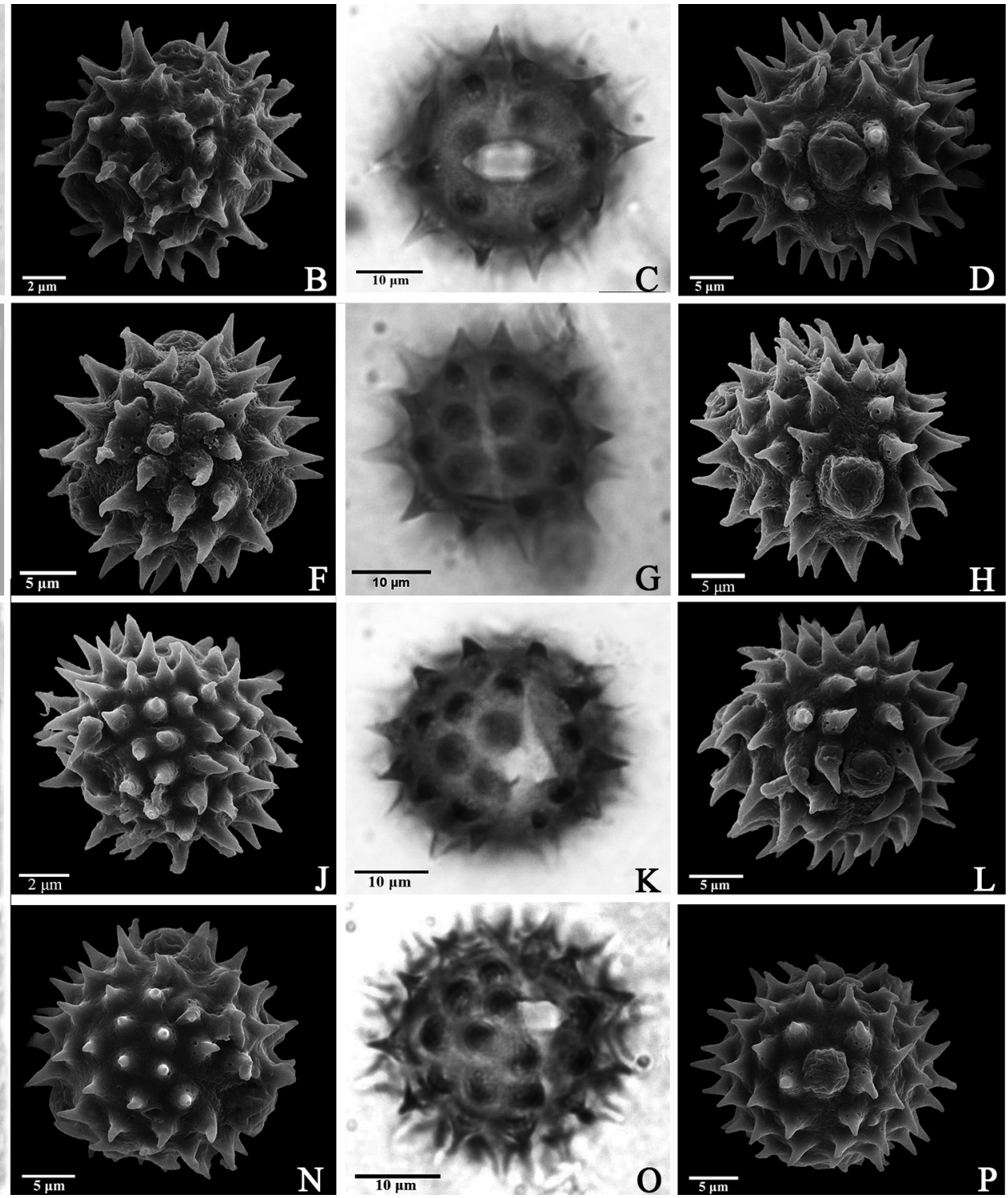

Figure 1. Photomicrographs and electromicrographis of pollen grains of Brazilian Verbesina L. (Heliantheae-Asteraceae) species. 1st and 3rd columns - Photomicrographs under light microscopy; 2nd and 4th columns - electromicrophis in SEM. Verbesina baccharifolia - polar view: A. optical section, B. general aspect; equatorial view: C. optical section, D. aperture. Verbesina bipinnatifida - polar view: E. optical section, F. general aspect, equatorial view: G. optical section, H. aperture. Verbesina floribunda - polar view: I. optical section, J. general aspect, equatorial view: K. general aspect, L. aperture. Verbesina glabrata - polar view: M. optical section, N. general aspect, equatorial view: $\mathbf{O}$. general aspect, $\mathbf{P}$. aperture. 

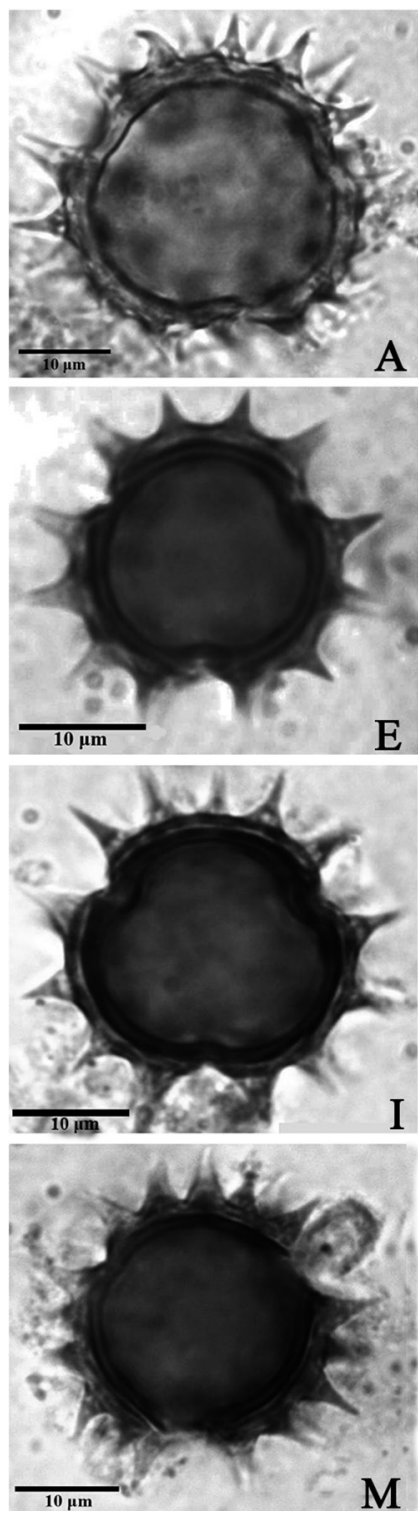
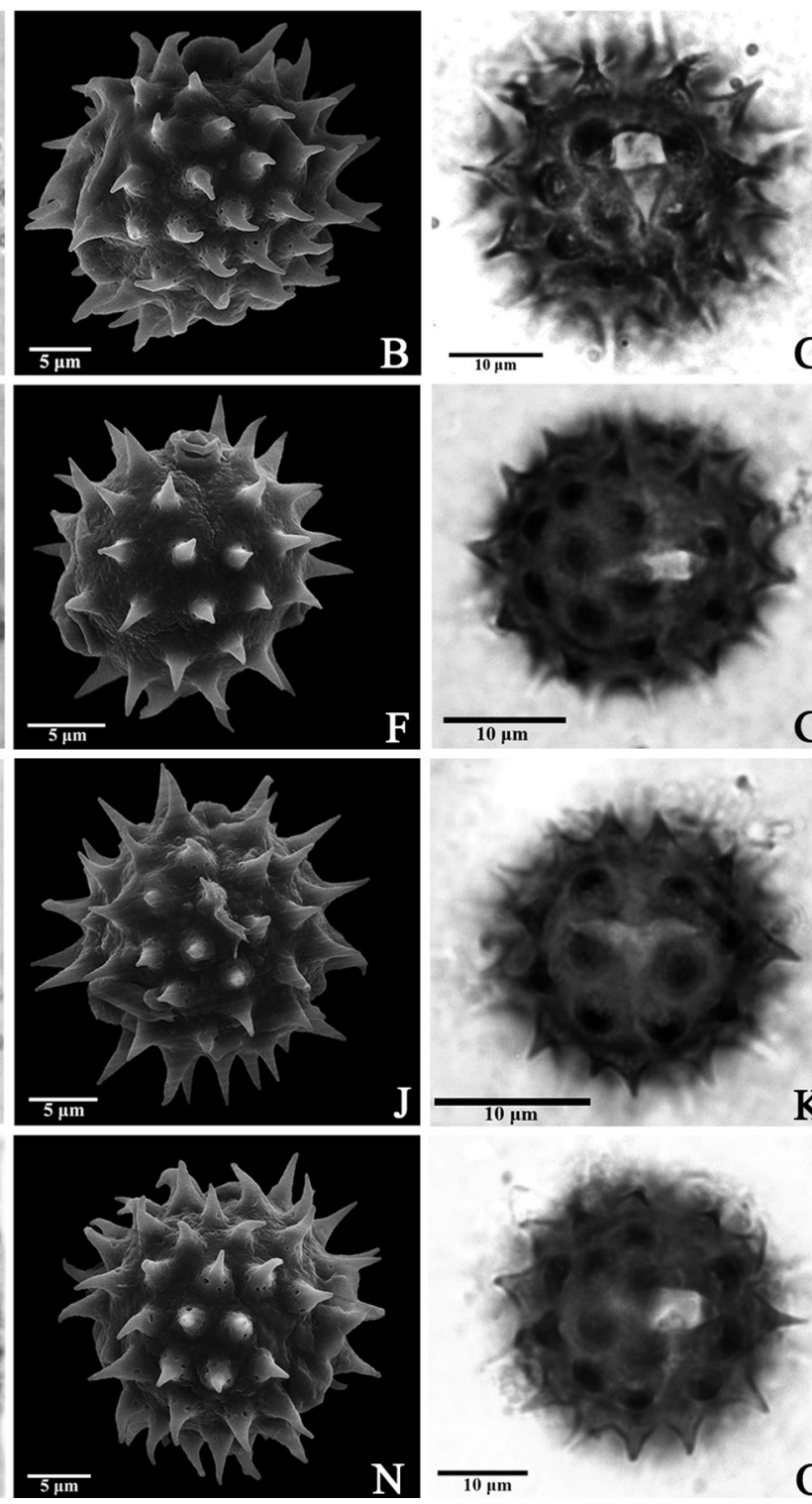

C
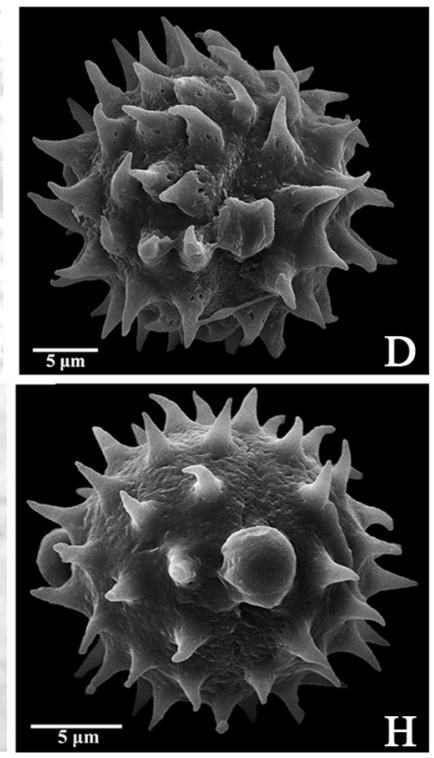

Figure 2. Photomicrographs and electromicrographis of pollen grains of Brazilian Verbesina L. (Heliantheae-Asteraceae) species. $1^{\text {st }}$ and $3^{\text {rd }}$ columns - Photomicrographs under light microscopy; $2^{\text {nd }}$ and $4^{\text {th }}$ columns - electromicrophis in SEM. Verbesina luetzelburgii polar view: A. optical section, B. general aspect; equatorial view: C. optical section, D. aperture. Verbesina macrophylla - polar view: E. optical section, F. general aspect, equatorial view: G. optical section, H. aperture. Verbesina nicotianifolia - polar view: I. optical section, J. general aspect, equatorial view: K. general aspect, L. aperture. Verbesina sordescens - polar view: M. optical section, N. general aspect, equatorial view: $\mathbf{O}$. general aspect, $\mathbf{P}$. aperture.

Table 5. Shape of pollen grains and presence of cavea reported in previous studies that dealt with Brazilian taxa of the genus Verbesina (Heliantheae-Asteraceae).

\begin{tabular}{|c|c|c|c|c|}
\hline Specie & Shape & Exine / thickness & Reference & Present study \\
\hline \multirow{2}{*}{ Verbesina glabrata Hook. \& Arn. } & prolate-spheroidal & - & Gonçalves 1976 & \multirow{2}{*}{$\begin{array}{l}\text { oblate-spheroidal to } \\
\text { prolate-spheroidal }\end{array}$} \\
\hline & spheroidal & not caveate & Cancelli et al. 2010 & \\
\hline \multirow{2}{*}{ Verbesina macrophylla (Cass.) S.F. Blake } & prolate-spheroidal & - & Gonçalves 1976 & \multirow{2}{*}{ oblate-spheroidal } \\
\hline & prolate-spheroidal & caveate & Jesus \& Lima 2013 & \\
\hline \multirow{4}{*}{ Verbesina sordescens DC. } & prolate-spheroidal & - & Gonçalves 1976 & \multirow{4}{*}{ oblate-spheroidal } \\
\hline & oblate-spheroidal & caveate & Cancelli et al. 2010 & \\
\hline & oblate-spheroidal & caveate & Radaeski et al. 2014 & \\
\hline & prolate-spheroidal & cavea / $1 \mu \mathrm{m}$ & Radaeski et al. 2016 & \\
\hline
\end{tabular}




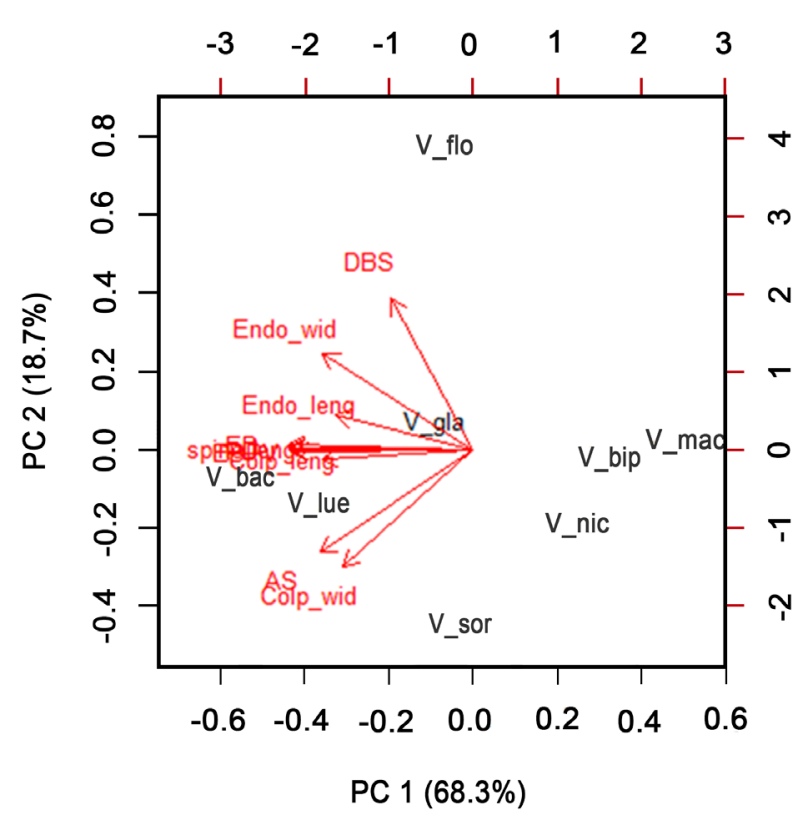

Figure 3. Analysis of principal components composed of metric variables of pollen from Verbesina L. (Heliantheae-Asteraceae). Variables in red mean: PD - polar diameter in equatorial view, ED - equatorial diameter, EDPV - equatorial diameter in polar view, AS - apocolpus side, colp-leng: colpus length, colp-wid: colpus width, endo-leng: length of endoaperture, endo-wid: width of endoaperture, spine-leng: length of spine, DBS - distance between spines. The species names are abbreviated.

consistent with the high coefficient of variation found, which in the present study ranged $4.6-10.4 \%$ for PD and $4.7-11.6 \%$ for ED, showing tha the shape of the pollen grain is variable.

The presence of a cavea has been reported to be very common in the tribe Heliantheae (Cancelli et al. 2007; Stanski et al. 2013; Radaeski et al. 2016). In some genera the cavea is evident and its thickness easily measured, as observed by Magenta et al. (2010) with Viguiera, for which it ranged $0.8-1.5 \mu \mathrm{m}$.

Due to the proximity of the sexine and nexine, the cavea in Verbesina is difficult to visualize, which can lead to the false impression of its non-existence, as pointed out by Cancelli et al. (2010) for Verbesina glabrata. Some studies of species of Verbesina did not indicate the presence of a cavea, while others indicated that only the exine is of the cavea; only Radaeski et al. (2016) reported measurements of the cavea, which was $1 \mu \mathrm{m}$ for V. sordescens (Tab. 5).

Although the pollen grains of the studied Brazilian species of Verbesina exhibited homogeneity of shape, aperture type, and ornamentation of the sexine, some attributes show potential usefulness for characterizing species, such as the distance between spines, and dimensions of the apocolpus side and aperture. Thus, these characters of pollen grains have potential taxonomic value for distinguishing species.

\section{Acknowledgements}

Thanks go to the Coordination of Improvement of Higher Education Personnel for the granting the doctoral scholarship to the first author; to the Federal District Research Support Foundation (FAPDF - 01/2016) for financial support; and to CNPq for a productivity grant (Vania Gonçalves-Esteves and Cláudia B.F. Mendonça).

\section{References}

Anderberg AA, Baldwin BG, Bayer RG, et al. 2007. Compositae. In: Kubitzki K. (ed.) The families and genera of vascular plants. New York, Springer. p. 61-87.

APG IV - The Angiosperm Phylogeny Group. 2016. An update of the Angiosperm Phylogeny Group classification for the orders and families of flowering plants: APG IV. Botanical Journal of the Linnean Society 181: 1-20.

Bolick MR. 1991. Pollen diameter, exine thickness, and ultrastructure type in the tribes of the Compositae. Compositae Newsletter 19: 17-21.

Cancelli RR, Cardoso A, Evaldt P, Bauermann SG. 2007. Catálogo palinológico de táxons da família Asteraceae Martinov. no Rio Grande do Sul - Parte I. Pesquisas, Botânica 58: 347-374.

Cancelli RR, Cardoso A, Evaldt P, Bauermann SG. 2010. Catálogo palinológico de táxons da família Asteraceae Martinov, no Rio Grande do Sul, Brasil. Iheringia, Série Botânica 65: 201-280.

Coutinho AP, Dinis AM. 2007. A contribution to the ultrastructural knowledge of the pollen exine in subtribe Inulinae (Inuleae, Asteraceae). Plant Systematics and Evolution 269: 159-170.

Erdtman G. 1952. Pollen morphology and plant taxonomy - Angiosperms. Stockholm, Almqvist and Wiksell.

Faegri G, Iversen J. 1966. Textbook of modern pollen analysis. Copenhagen, Scandinavian University Books.

Flora do Brasil 2020 em construção. 2018. Asteraceae. Jardim Botânico do Rio de Janeiro. http://floradobrasil.jbrj.gov.br/reflora/floradobrasil/ FB55. 26 Jan. 2018.

Funk VA, Susanna A, Stuessy TF, Robinson H. 2009. Classification of Compositae. In: Funk VA, Susanna A, Stuessy TF, Bayer RJ. (eds.) Systematics, evolution, and biogeography of Compositae. Vienna, Austria, IAPT. p. 171-176.

Gonçalves VB. 1976. Contribuição ao estudo palinológico da Tribo Heliantheae (Compositae). Revista Brasileira de Biologia 36: 157-166.

Gonçalves-Esteves V, Esteves R. 1986. Contribuição ao estudo polínico da tribo Heliantheae (Compositae) IV. Boletim do Museu Nacional, Botânica 74: 1-14.

Gonçalves-Esteves V, Esteves R. 1989a. Contribuição ao estudo polínico da tribo Heliantheae (Compositae) VI. Boletim do Museu Nacional, Botânica 80: 1-11.

Gonçalves-Esteves V, Esteves R. 1989b. Contribuição ao estudo polínico da tribo Heliantheae (Compositae) VII. Boletim do Museu Nacional, Botânica 82: 1-11.

Harker M, Jiménez-Reyes N. 2002. Verbesina barrancae (Compositae, Heliantheae), a new species from Jalisco, Mexico. Brittonia 54: 181189.

Jesus EA, Lima LCL. 2013. Morfologia polínica de espécies de Asteraceae ocorrentes em uma área de Mata Ombrófila Densa, Alagoinhas, Bahia, Brasil. In: XVII Jornada de Iniciação Científica, Universidade do Estado da Bahia. p. 1-2.

Magenta MAG, Nunes AD, Mendonça CBF, Gonçalves-Esteves V. 2010. Palynotaxonomy of Brazilian Viguiera (Asteraceae) Species. Boletín de la Sociedad Argentina de Botánica 45: 285-299.

Melhem TS, Cruz-Barros MAV, Corrêa AMS, Makino-Watanabe H, SilvestreCapelato MSF, Gonçalves-Esteves V. 2003. Variabilidade polínica em plantas de Campos de Jordão (São Paulo, Brasil). Boletim do Instituto de Botânica 16: 9-104. 
Panero JL. 2007. Tribe Heliantheae - Verbesina. In: Kubitzki K. (ed.) The families and genera of vascular plants. [s.l.]. New York, Springer. p 440-477.

Panero JL, Crozier BS. 2016. Macroevolutionary dynamics in the early diversification of Asteraceae. Molecular Phylogenetics and Evolution 99: 116-132.

Panero JL, Freire SE, Espinar LA, Crozier BS, Barboza GE, Cantero JJ. 2014. Resolution of deep nodes yields an improved backbone phylogeny and a new basal lineage to study early evolution of Asteraceae. Molecular Phylogenetics and Evolution 80: 43-53.

Radaeski JN, Evaldt ACP, Bauermann SG, Lima GL. 2014. Diversidade de grãos de pólen e esporos dos campos do Sul do Brasil: descrições morfológicas e implicações paleoecológicas. Iheringia, Série Botânica 69: 107-132.

Radaeski JN, Evaldt ACP, Bauermann SG. 2016. Morfologia polínica de espécies da família Asteraceae Martinov nos Cerros da Campanha do Rio Grande do Sul, Brasil. Iheringia, Série Botânica 71: 357-366.

Roubik DW, Moreno JE. 1991. Pollen and spores of Barro Colorado Island. Vol. 36. St. Louis, Missouri Botanical Garden.

Salgado-Labouriau ML. 1973. Contribuição à palinologia dos cerrados. Rio de Janeiro, Academia Brasileira de Ciências.
Sanchez AC, Lupo LC. 2009. Asteraceae de Interés en la Melisopalinología. Bosque Montano de las Yungas (Jujuy - Argentina). Boletín de la Sociedad Argentina de Botánica 44: 57-64.

Skvarla J, Turner BL. 1966. Systematic implications from electron microscopic studies of Compositae pollen- A review. Annals of the Missouri Botanical Garden 53: 220-256.

Stanski C, Luz CFP, Nogueira A, Nogueira MKFS. 2013. Palynology of species in the Astereae and Heliantheae tribes occurring in the region of Campos Gerais, Paraná State, Brazil. Iheringia, Série Botânica 68: 203-214.

Stanski C, Nogueira NKFS, Luz CFP. 2016. Palinologia de espécies de Asteraceae de utilidade medicinal para a região dos Campos Gerais, Ponta Grossa, PR, Brasil. Hoehnea 43: 349-360.

Thiers B. 2017. Index Herbariorum: A global directory of public herbaria and associated staff. New York Botanical Garden's Virtual Herbarium. http://sweetgum.nybg.org/ih. 10 nov. 2017.

Wortley AH, Funk VA, Robinson H, Skvarla JJ, Blackmore S. 2007. A search for pollen morphological synapomorphies to classify rogue genera in Compositae (Asteraceae). Review of Palaeobotany and Palynology 146: 169-181. 